\title{
Surface markers of hepatocellular cancer stem cells and their clinical potential
}

\section{Minireview}

D. FENG ${ }^{1, *}, \mathrm{~N} . \mathrm{WANG}^{1, *}, \mathrm{~J} \cdot \mathrm{HU}^{1,2}, \mathrm{~W} \cdot \mathrm{LI}^{1, *}$

${ }^{1}$ The Cancer Center, the First Hospital of Jilin University, Changchun 130021, China; ${ }^{2}$ VA Palo Alto Health Care System and Stanford University Medical School, Palo Alto, CA, 94304, USA

${ }^{*}$ Correspondence: drweili@yahoo.com

${ }^{*}$ Contributed equally to this work.

\section{Received December 4, 2013 / Accepted February 10, 2014}

\begin{abstract}
Cancer stem cells (CSCs) are a small subpopulation of cells within tumors with capabilities of self-renewal, differentiation, and tumorigenicity when transplanted into immune-comprised mice. Accumulating evidences have shown that CSCs or tumor-initiating cells are key drivers of tumor formation and progression in both solid tumors and haematological malignancies. Identification of the CSCs or tumor-initiating cells is a fundamental and important problem in cancer research. There is still a lack of consensus regarding the existence of a "global" marker for CSCs in different human cancers, but isolated CSCs have shown both the tumor-propagating ability in immune-compromised mice and the capacity to fully recapitulate the original heterogeneity of cell types. Several cell surface markers, including CD133, CD44 and CD90, were often used to identify and enrich CSCs. Although not all types of cancer follow the CSC theory, it provides an attractive cellular mechanism to account for the therapeutic resistance and recurrence of the disease. Here we provide a brief review regarding the markers for identification of CSCs in hepatocellular cancer, allowing us to deep understand of the cellular organization of HCC and to develop therapies that target specific CSCs.
\end{abstract}

Key words: cancer stem cells, surface marker, CD133, CD44, CD90, EpCAM

Hepatocellular carcinoma (HCC) is the fifth most prevalent cancer and the third most frequent cause of cancer-related death [1]. During the past two decades, the incidence of HCC in the United States has tripled, while the 5-year survival rate has remained below $12 \%$ [2]. Great efforts have been made in treatment of HCC in the past decade. However, recurrence after ablation or resection is a major drawback. The difficulty in eradicating tumors may be due to the fact that conventional treatments target the bulk of the tumor cells leaving behind the cancer stem cells, which like their normal counterparts, maintain the ability to initiate tumorigenicity [3]. According to this hypothesis, identifying and killing cancer stem cells (CSCs) may be an effective treatment modality.

Recently, accumulating data support that the problem of relapse as well as drug resistance in cancers may well be a function of CSCs within the tumor [4]. CSCs have been identified in both solid tumors and haematological malignancies, including breast [5, 6], liver [7-9], brain, colorectal [10-12], lung [13, 14], pancreatic $[15,16]$, and multiple myeloma [17]. Various cell surface markers have been used for the isolation and characterization of CSCs from solid tumors, for example, CD133, CD24, CD44, CD90, epithelial cell adhesion molecule (EpCAM), THY1, ATP-binding cassette B5 (ABCB5) and aldehyde dehydrogenase $1(\mathrm{ALDH} 1)$. There is still a lack of a global marker of CSCs, but the identification of CSC has profound implications for understanding the mechanisms of HCC and for the design of novel and specific therapeutic strategies. Here we provide a brief review regarding the markers for identification of CSCs in hepatocellular cancer, and hope these studies may contribute to diagnosis and 
prognosis prediction in patients with HCC, as well as improve HCC patients' survival.

\section{Characteristics of CSCs}

Two models have been proposed to explain tumor heterogeneity, including the stochastic model and the hierarchical model [18]. The stochastic model postulate that all tumor cells within tumor bulk are biologically homogenous and have an equal capacity to regenerate a tumor. While the hierarchical model, also termed the CSCs model, suggests that only a small subset of tumor cells within tumor bulk exhibit the capacity to initiate and sustain tumor growth. According to this CSCs model, these cells present unlimited proliferation potential, ability to self-renew, and capacity to generate a progeny of differentiated cells that constitute the major tumor population. CSCs can divide asymmetrically, producing an identical daughter cell and a more differentiated cell [19]. In contrast to differentiated tumor cells, CSCs are relatively quiescent and have a slow cycling rate[20]. CSCs also have the ability to form tumors when they are injected into non-obese diabetic/severe combined immunodeficiency (NOD/SCID) mice[21-24]. Characteristically, CSCs are also radiotherapy and chemotherapy-resistant. Potent tumor initiation, selfrenewal and differentiation are the common characteristics of CSCs [25-28]. Studies have now demonstrated that CSCs exhibit many classical properties as follows [29]: (i) a high selfrenewal capacity; (ii) an enhanced ability to differentiate and generate heterogeneous lineages; (iii) an increased capacity for self-protection against drugs, toxins and radiation; and (iv) an increased capacity to initiate and sustain tumor growth.

\section{Markers for identification and isolation of liver cancer stem cells}

CSCs could be selected through functional assays, such as isolating side population (SP) cells by Hoechst dye staining and screening cells with activity of ALDH. In recent years, Fluorescence-activated cell sorting and magnetic activated cell sorting analyses are two most common methods to identify

Table 1. Common characteristics of cancer stem cells

\footnotetext{
* Potent tumor initiation-CSCs should regenerate the tumor when limited number cells are injected into mice.

* Self-renewal - the ability of a cell to reproduce itself without losing developmental potential. Direct evidence of CSCs self-renewal is achieved by observing regrowth of a phenotypically identical and heterogeneous tumor.

* Differentiation - the ability to give rise to a heterogeneous progeny of cells, which progressively diversify and specialize according to a hierarchical process, constantly replenishing the tissue of short-lived, mature elements. CSCs should demonstrate some differentiation capacity reflecting the tumor. Tumors arising in vivo should represent a phenocopy of the original human tumor.
}

and isolate CSCs. Compelling data have shown that hepatic CSCs could be isolated by several different cell markers, i.e., CD133, CD24, CD44, CD90, CD13, EpCAM and OV6.

\section{Side population cells (SP cells)}

SP cells were first isolated from hematopoietic stem cells (HSC) in 1996. Goodell Ma et al [30] used Hoechst 33342 to stain murine bone marrow cells, and discovered that a small subset of cells were shown to have phenotypic markers of multipotential HSC and to be enriched at least 1,000-fold for in vivo reconstitution activity. Further, these Hoechst-stained cells were shown to protect recipients from lethal irradiation at low cell doses, and to contribute to both lymphoid and myeloid lineages. These cells were called SP cells. After that, SP cells were identified in various cancer cell lines. Chiba and colleagues [31] detected SP cells in Huh-7 and PLC/PRF/5 cells. Compared to non-SP cells, SP cells exhibited high proliferative potential and anti-apoptotic properties. In vivo, only $1 \times 10^{3}$ SP cells were sufficient for tumor formation in NOD/SCID xenograft transplant experiments, whereas an injection of 1 x $10^{6}$ non-SP cells did not initiate tumors. Re-analysis of SP cell-derived tumors showed that SP cells generated both SP and non-SP cells and tumor-initiating potential was maintained only in SP cells in serial transplantation. Several "stemness genes" were upregulated in SP cells, but not in non-SP cells. Zhou $S$ et al [32] further found that the SP phenotype was determined by expression of the Bcrp1/ABCG2 gene. Koichi Shimano et al [33] showed that hepatic oval cells, which possess several characteristics of stem cells, had the SP phenotype. The expression pattern of ABCG2/BCRP1 mRNA level was well correlated with the number of oval cells. These data support that SP cells can serve as a maker of cancer stem cells.

However, several criticisms have been raised concerning the use of Hoechst dye as a means of isolating stem-like cells. There are many variables involved in the preparation and staining for isolation of SP cells by FACS. Because efflux of a dye is a dynamic process, slight variations can dramatically affect the viability, homogeneity, and apparent yield of SP cells in tissue dissociation [34, 35]. Xu Y et al [36] found that four factors in the staining process influenced SP percentage, including incubation time, shaking interval, culture time and Hoechst 33342 concentration. In addition, Hoechst dye renders the assay toxic to live cells, so it can be argued that SP cells are only a population of cells that are able to escape the lethal effects of Hoechst[3]. As a result, there are often large discrepancies between SP abundances from the same tissue. We believe that SP cells should not be used alone for stem cell purification, and they at least need to be validated in combination with other markers.

\section{ALDH}

In addition to identification of CSCs by SP analysis, ALDH activity is another functional marker of CSCs. Long before 
ALDH activity was used as a marker for identifying CSCs, the potential role of ALDH in chemoresistance had already been identified. There are 17 isoforms of ALDH in the human body that also localize to the mitochondria in addition to cytosol[37], and ALDH1 has been extensively analysed in candidate CSCs as a potential marker for CSCs. Ginestier et al [38] found that ALDEFLUOR-positive breast cancer cells that had ALDH activity were capable of forming xenograft tumors with as little as 500 cells. ALDEFLUOR-negative cells from the same tumor samples, however, were unable to form xenograft tumors with as many as 50,000 cells. When ALDEFLUOR-positive staining was combined with CD44 (+)/CD24 (-) markers, as little as 20 breast cancer cells could form tumors. Ma and colleagues [9] analysed the expression of several different ALDH isoforms and ALDH enzymatic activity in liver cell lines and found that ALDH was positively correlated with CD133 expression by dual-color flow cytometry. They also reported that the majority of ALDH (+) HCC cells were CD133 (+), yet not all CD133 (+) HCC cells were ALDH $(+)$. Subsequent studies found that CD133 (+) ALDH (+) cells were significantly more tumorigenic than their counterparts, CD133(-) ALDH (+) or CD133 (-) ALDH (-). These data suggested that ALDH, combined with $\mathrm{CD} 133$, could more specifically characterize the tumorigenic liver CSC population.

\section{CD133}

Human CD133 is a five transmembrane single-chain glycoprotein that belongs to the prominin family containing two large extracellular and two small intracellular loops. The glycosylated forms have a molecular mass of $\approx 115 \sim 120$ $\mathrm{kDa}$ [39-41]. The role of CD133 as a CSC marker has been documented in various tissues, including lung cancer [42-46], gastric carcinoma [47, 48], pancreatic cancer [49-51], colon cancer [52-55], as well as liver cancer $[9,56,57]$.

CD133 (+) HCC cells were first reported to represent a potential CSC subpopulation in HCC by Suetsugu and colleagues [58]. They found that CD133 (+) cells from Huh-7 performed a higher proliferative potential than $\mathrm{CD} 133(-)$ population of Huh-7 cells. CD133 (+) Huh-7 were subcutaneously injected into SCID mice, and finally formed tumors; whereas CD133 (-) Huh-7 cells induced either a very small number of tumors or none at all. Ma et al [7] showed that CD133 (+) cells possessed a greater colony-forming efficiency, higher proliferative, and greater ability to form tumor in vivo. These cells were endowed with expression of "stemness" genes, the ability to self-renew, and the ability to differentiate into nonhepatocyte-like lineages. Furthermore, CD133 was found to represent only a minority of the tumor cell population in human HCC specimens. Another group obtained that CD133 similar findings (+) fraction from a SMMC-7721 cell line demonstrated an enhanced clonogenicity in vitro and tumorigenicity in vivo [8]. CD133 (+) and CD133 (-) fractions from HCC cell lines were then subjected to functional analyses in vitro and xenograft transplantation in vivo by $\mathrm{Ma}$ and colleagues [59]. They suggested that CD133(+) cells possessed the preferential ability to form undifferentiated tumor spheroids in vitro, expressed an enhanced level of stem cell-associated genes and had a greater ability to form tumors when implanted orthotopically in immunodeficient mice. Xenografts resembled the original human tumor and maintained a similar percentage of tumorigenic CD133 (+) cells. With over $70 \%$ of the mouse liver removed, the expression of prominin-1, the homolog of human CD133 in mice, was found to be significantly upregulated during early liver restoration [29].

\section{CD24}

CD24 is a small, heavily glycosylated and mucin-like cell surface glycoprotein, has been shown to be highly expressed in stem/progenitor cells and has been linked to CSCs derived from breast, colon, ovarian, pancreatic $[18,60]$. Huang et al [61] first cloned the full-length CD24 cDNA sequence from human HCC and found that CD24 mRNA overexpression was common in HCC cells in parallel with p53 mutation and tumor differentiation. There was a strong correlation between CD24 mRNA overexpression and p53 gene mutation in HCC and poorly differentiated HCC. With regard to hepatocellular cancer stem cells, Lee et al [23] found CD24 was upregulated in residual chemoresistant tumors upon cisplatin treatment in immunocompromised mice model. CD24 (+) HCC cells were critical for the maintenance of self-renewal differentiation and metastasis of tumors. As few as 500 CD24 (+) cells from HCC cell lines are sufficient for consistent tumor development in NOD/SCID mice. As few as 4,000 CD24 (+) cells from primary HCC specimens could initiate tumors. CD24 was found to be a functional liver tumor-initiating cells (T-IC) marker that drives T-IC genesis through STAT3-mediated NANOG regulation with lentiviral-based knockdown approach. They further demonstrated that majority CD24 (+) HCC cells also were positive for CD133 and EpCAM.

\section{CD44}

CD44 is a transmembrane glycoprotein involved in the interaction between cells and extracellular matrix [62], several variant forms of $\mathrm{CD} 44$ have been reported, isoform CD44 RNA $(\mathrm{CD} 44 \mathrm{~V})$ was recognized in three metastasized hepatocellular carcinoma cell lines, J5, HCC36, and HEP3B [63]. Restricted expression of CD44s and CD44v6 were revealed by using the DNA microarray and RT-PCR in small hepatocytes (SHs), which were hepatic progenitor cells. Sorted CD44s (+) cells could form colonies and possessed hepatic markers [64]. Cogliati et al [65] searched for stem/progenitor cells in 13 HCC and $7 \mathrm{CC}$ archived samples by immunohistochemical analysis. They found that both liver tumors presented a higher amount of K19 (+) HPCs. Further, $61.6 \%$ of HCC cases presented immature CD44 (+) hepatocytes. Nevertheless, only two cases presented CD133 $(+)$ cells. Zhu et al [66]demonstrated that CD133(+) CD44 (+) HCC cells showed stem cell properties, 
including extensive proliferation, self-renewal, and differentiation into the bulk of cancer cells. CD133 (+) CD44 (+) cells showed more highly tumorigenic capacity than their CD133 (+) CD44 (-) counterparts in vivo xenograft experiments. Moreover, cells double-positive for CD133 and CD44 exhibited preferential expression of some stem cell-associated genes and were more resistant to chemotherapeutic agents due to the upregulation of ATP-binding cassette (ABC) superfamily transporters, further supporting these cells as HCC cell origin. It was suggested that CSC phenotype could be precisely defined by co-expression of CD133 and CD44 cell surface markers.

\section{CD90}

CD90 (Thy-1) is a $25-37 \mathrm{kDa}$ glycosylphosphatidylinositol (GPI) -anchored glycoprotein expressed on many cell types, including T cells, thymocytes, neurons, endothelial cells, and fibroblasts. CD90 is an important regulator of cell-cell and cell-matrix interactions, with important roles in nerve regeneration, metastasis, inflammation, and fibrosis [67]. Recently, CD90 has also received attention as a cancer stem cell marker in various tumor cells, including hepatic stem cells. Yang et al [68] showed that the CD90 (+) cells, but not the CD90 (-) cells, from HCC cell lines displayed tumorigenic capacity. All the tumor specimens and $91.6 \%$ of blood samples from liver cancer patients bore the CD45 (-) CD90 (+) population, which could generate tumor nodules in immunodeficient mice. The CD90 (+) CD44 (+) cells demonstrated a more aggressive phenotype than the CD90 (+) CD44 (-) counterpart and formed metastatic lesions in the lung of immunodeficient mice. CD44 blockade prevented the formation of local and metastatic tumor nodules by the CD90 (+) cells. CD90 as a potential marker was delineated CSCs serially from HCC cell lines, human liver cancer specimens and blood samples [69]. The number of CD90 (+) cells from HCC cell lines increased with the tumorigenicity. All the tumor specimens stained positive for CD45 (-) CD90 (+) cells, but not in the normal, cirrhotic, and parallel nontumorous livers. In addition, CD45 (-) CD90 $(+)$ cells of blood samples from liver cancer patients account for about $90 \%$, but none in normal subjects or patients with cirrhosis. CD90 (+) cells sorted from cell lines and CD45 (-) CD90 (+) cells from the tumor tissues and blood samples of liver cancer patients formed tumor nodules in immunodeficient mice. Serial transplantation of CD90 (+) cells from tumor xenografts generated tumor nodules in a second and subsequently third batch of immunodeficient mice. CD45 (-) CD90 (+) cells accounted for a very low number (0\%-0.05\%) of in the normal, cirrhotic, and parallel non-tumorous livers by flow cytometry. However, CD45 (-) CD90 (+) cells were detected in all the tumor tissues, but not in the normal, cirrhotic, and parallel non-tumorous livers. CD90 (+) cells were detected in tumor tissues, with both scattered and clustered patterns by IHC. Several other stem cell markers were also demonstrated in the tumor tissues, such as CD133, ESA, CXCR4, CD24, KDR and CD44. There was a significant posi- tive correlation between the number of CD45 (-) CD90 (+) cells in the tumor tissues and the number of CD45 (-) CD90 $(+)$ cells in the blood samples.

\section{CD13}

CD13, also known as aminopeptidase $\mathrm{N}$, is a membranous glycoprotein that plays important roles in cancer progression including cell proliferation, invasion, and angiogenesis [70-72]. Christ et al [73] demonstrated that CD13(+) cells predominated in the G0 phase of the cell cycle and typically formed cellular clusters in cancer foci. CD13 reduced ROS-induced DNA damage after genotoxic chemo/radiation stress and protected cells from apoptosis. Compared with either agent alone, tumor volume was drastically reduced by treatment of combination a CD13 inhibitor with the geotaxis chemotherapeutic fluorouracil (5-FU) in mouse xenograft models. 5-FU inhibited CD90 (+) proliferating CSCs, some of which produce CD13 $(+)$ semiquiescent CSCs, while CD13 inhibition suppressed the self-renewing and tumor-initiating ability of dormant CSCs. They argued that combining a CD13 inhibitor with a ROS-inducing chemo/radiation therapy could improve the treatment of liver cancer. They further demonstrated that CD13 was a marker for semiquiescent CSCs in human liver cancer cell lines and clinical samples and that targeting these cells might provide a way to treat this disease. Nagano and colleagues [74] found that CD13 was a surface marker for CSCs in human liver cancer cell lines and clinical samples, and that CD13 (+) CSCs were associated with a hypoxic marker in clinical hepatocellular carcinoma sample, suggesting that CD13(+) CSCs have the critical role in tumor growth and resistance to anti-cancer therapy in liver cancers.

\section{EpCAM}

EpCAM is a homophilic, $\mathrm{Ca}^{2+}$-independent cell-cell adhesion molecule that is expressed in many human epithelial tissues. Its increased expression is closely associated with active cell proliferation. Furthermore, in epithelial cell types that lack EpCAM in adults, upregulation of EpCAM coincides with the early stages of neoplastic change [75]. EpCAM was identified in 2008 as a marker for human embryonic stem cells in an antibody-based screening assay [76]. In 2010, Terris et al [75] revealed that the EpCAM (+) AFP (+) HCC subtype had features of hepatic stem/progenitor cells with gene expression and pathway analyses. EpCAM (+) HCC cells isolated by the fluorescence-activated cell sorting displayed hepatic cancer stem cell-like traits including the abilities to self-renew and differentiate. Moreover, these cells were capable of initiating highly invasive HCC in nonobese diabetic, severe combined immunodeficient mice. Chen et al [77] found that CD133(+) EpCAM $(+)$ cells possessed many characteristics of TICs in Huh-7 cells, including higher differentiation capacity, increased colony-formation ability, preferential expression of stem cell-related genes, drug-resistant to some chemothera- 
peutics, more spheroid formation of culture cells and stronger tumorigenicity in NOD/SCID mice. In 2013, Yamashita et al [78] showed that CSC markers EpCAM and CD90 was independently expressed in liver cancer. In primary HCC, EpCAM $(+)$ and CD90 (+) cells resided distinctively, and gene-expression analysis of sorted cells suggested that EpCAM $(+)$ cells had features of epithelial cells, whereas CD90 (+) cells had those of vascular endothelial cells. Serial xenotransplantation of EpCAM (+) / CD90 (+) cells from primary HCCs in immune-deficient mice revealed rapid growth of $\operatorname{EpCAM}(+)$ cells in the subcutaneous lesion and a highly metastatic capacity of CD90 (+) cells in the lung.

\section{OV6}

OV6 is a monoclonal antibody isolated from carcinogentreated rat liver [18]. Recently, OV6, a marker of oval cells, is used as a hepatic stem cell marker [79, 80]. In 2008, Yang et al [81] reported that OV6 (+) HCC cells had a greater tumorigenic ability in NOD/SCID mice when compared with OV6 (-) cells and resistance to standard chemotherapy. Moreover, Wnt pathway activation was able to enriched OV6 (+) cells, and inhibition of $\beta$-catenin signalling decreased in the proportion of OV6 cells. In 2012, they [82] further demonstrated that these OV6 (+) HCC cell not only possessed a higher capacity to form tumor spheroids in vitro, but also exhibited more invasive and metastatic potentials both in vitro and in vivo. These results suggested that OV6 (+) HCC cells possessed self-renewal capacity and tumorigenicity, and $\mathrm{Wnt} / \beta$-catenin pathway played the importance role in the activation and expansion of OV6 (+) populations within tumors. Therefore, OV6 also might be a hepatic CSC marker.

\section{DLK1 (Delta-like 1 homolog)}

DLK1 is known to be expressed in fetal liver, but absent in neonatal and adult liver in mice and rats [83]. Up-regulation of DLK was found in $73.2 \%$ of HCC specimens due to genomic methylation [84]. DLK1 (+) cells were found in all 17 HCC cell lines and exhibited stronger ability of in vitro clonogenicity and in vivo tumorigenicity in mice. Moreover, some known stem/progenitor cell-like markers were found upregulated, such as Nanog, SMO, SOX2, Oct3/4, CD133, CD90, and EpCAM. The sorted DLK1 (+) HCC cells are highly resistant to conventional chemotherapy drug, such as doxorubicin, cisplatin, epirubicin, and 5-FU. Knockdown of DLK1 suppressed CSCs traits including proliferation, spheroid formation and tumorigenicity. Adenoviral-mediated RNA interference against DLK1 attenuated the in vivo tumorigenicity of HCC cells [21].These features of DLK1 (+) HCC cells are consistent with known characteristics of CSCs and DLK1 $(+)$ was able to use to identify CSCs of liver.

Taken together, considerable effort has been made in the detection and characterization of CSCs markers. We can use these makers to identify and isolate a minority of cancer cells from various hepatocellular cell lines, which possess feature of CSCs, including proliferation, spheroid formation tumorigenicity and resistance to chemotherapeutic drugs. These findings provided deeper insight into HCC stem cells. However, we should note that not all sorted cells are CSCs; some markers are indeed more or less specific for hepatic CSCs. More important, we have not found a global marker to isolate hepatic CSCs. Therefore, further studies need to be carried out for accurate characterization the CSCs of liver.

\section{Clinical implications of CSCs surface markers}

Recently, different markers were used to identify hepatic CSCs and subsequently several deregulated molecular pathways were discovered in hepatic CSCs. Thus, hepatic CSCs were believed to be responsible for metastasis and recurrence. Further studies have demonstrated that the markers may contribute to diagnosis, therapeutic, prognosis potential in patients with HCC. These shed lights on the potential utility of hepatic CSCs in assisting HCC clinical management.

\section{Diagnostic potential}

Hepatic CSCs markers were used not only for identification and isolation CSCs, but also for HCC early diagnosis. Recently, Yang et al $[68,69]$ identified CD45 (-) CD90 (+) hepatic CSCs in 31 out of 34 blood samples from liver cancer patients by flow cytometry, but not in normal controls or patients with cirrhosis. Sorted CD45 (-) CD90 (+) cells were injected into the liver of SCID/Beige mice. Four months after cells injection, tumor formation was detected in 5 out of 10 mice. Further serial transplantation of CD90 $(+)$ cells from tumor xenografts could generate tumors in a second and subsequently a third batch of immunodeficient mice. Moreover, CD90 (+) cells were detected in the tumor xenograft by IHC. These results suggest that examination of CD45CD90 cells in blood might provide a novel diagnostic method for human HCC.

\section{Therapeutic potential}

Yang et al [68] investigated expression relationship between CD44 and CD90 in vivo and in vitro experiments. They found that administration of anti-CD44 antibody was able to induced apoptosis of the CD90 (+) andCD90 (-) cells isolated from MHCC97L cell line in a dose-dependent manner. However, blockade of CD44 activity in PLC cell line only induced the CD90 (+) cells to undergo apoptosis and had a mild effect on the CD90 (-) cells. In vivo, different doses of anti-CD44 antibody were administered into nude mice at the time of cell inoculation. In the absence of anti-CD44 antibody administration, the $\mathrm{CD} 90(+)$ cells resulted in tumor formation subcutaneously in more than $80 \%$ of nude mice. Treatment with different dose anti-CD44 antibody was able to decrease the number of tumor-bearing mice, even though $10 \mathrm{mg} / \mathrm{kg}$ further inhibit tumor formation. Most importantly, 
administration of anti-CD44 antibody prevented metastatic lesions in the liver and lung induced by CD90 (+) cells. Those findings highlight the potential of targeting CD90 (+) CD44 (+) CSCs for tumor eradication in future therapeutic strategies. Yamashita et al [22] reported that EpCAM blockage via RNA interference dramatically decreased the population of EpCAM (+) cells, and significantly inhibited cellular invasion, spheroid formation and tumorigenicity of $\mathrm{HuH} 1$ cells. Their data suggest that EpCAM may serve as a molecular target to eliminate HCC cells with stem/progenitor cell features. Yang et al [82] the property of OV6 (+) CSC cells was sustained by recombinant stromal cell-derived factor-1 (SDF-1), and this effect was blocked by a specific CXCR4 inhibitor, AMD3100, or transfection of siRNA targeting CXCR4.

\section{Prognostic potential}

In 2013, Yamashita et al [78] used EpCAM and CD90 evaluate the clinicopathological characteristics of surgically resected HCC cases. The results showed that EpCAM (+) cells ( $\geq 5 \%$ ) was characterized by poorly differentiated morphology and high serum AFP values with a tendency for portal vein invasion, whereas the existence of CD90 $(+)$ cells $(\geq 5 \%)$ was associated with poorly differentiated morphology and a tendency for large tumor size. Notably, CD90 (+) cells was associated with a high incidence of distant organ metastasis. These results indicated that EpCAM $(+)$ cells was associated with poorly differentiated morphology and high serum alphafetoprotein (AFP), whereas CD90 (+) cells was associated with a high incidence of distant organ metastasis. They also revealed $[22,85]$ that EpCAM (+) AFP (+) HCC has progenitor features with poor prognosis by gene expression profiles, whereas EpCAM (-) AFP (-) HCC have adult hepatocyte features with good prognosis. Yang et al [86] showed that patients with more OV6 (+) tumor cells were associated with aggressive clinicopathological features and poor prognosis.

\section{Future challenge}

Identification and isolation of hepatic CSCs is a fundamental research. Hepatic CSCs can be identified by several markers, such as CD133, CD24, CD44, CD90, EpCAM, CD13, and SP cells by Hoechst 33342 staining and ALDH activity. Although CSCs have showed the tumor-propagating ability and the capacity to fully recapitulate the original heterogeneity of cell types, there is still a lack of consensus and the existence of a "global" marker for CSCs in liver cancers. Not all isolated cells by CSC markers were CSCs, and the number of CSCs vary depending on marker and cell lines. Sometimes the number of CSCs are also different even when the same marker and cells are used. Our understanding of hepatic CSCs remains limited. Although various types of identified hepatic CSCs have similar "stem-like" characteristics, their similarities and differences in underlying molecular signalling pathways are not well defined. Combinations of several markers may be of value in identifying hepatic CSCs in the future, and the identification of new CSCs would have more profound implications for understanding the mechanisms of invasion (metastasis) and for the design of novel and tumor-specific therapeutic strategies.

Acknowledgements: This work was supported by grants from National Natural Science Foundation for Young Scholars, China (NO. 81201673).

\section{References}

[1] FORNER A, LLOVET JM, BRUIX J. Hepatocellular carcinoma. Lancet 2012; 379: 1245-1255. http://dx.doi.org/10.1016/ S0140-6736(11)61347-0

[2] EL-SERAG HB.HEPATOCELLULAR CARCINOMA. N Engl J Med 2011; 365: 1118-1127. http://dx.doi.org/10.1056/ NEJMra1001683

[3] WU C, ALMAN BA. Side population cells in human cancers. Cancer Lett 2008; 268: 1-9. http://dx.doi.org/10.1016/ j.canlet.2008.03.048

[4] FULDA S, PERVAIZ S. Apoptosis signaling in cancer stem cells. Int J Biochem Cell Biol 2010; 42: 31-38. http://dx.doi. org/10.1016/j.biocel.2009.06.010

[5] AL-HAJJ M, WICHA MS, BENITO-HERNANDEZ A, MORRISON SJ, CLARKE MF. Prospective identification of tumorigenic breast cancer cells. Proc Natl Acad Sci U S A 2003; 100: 3983-3988. http://dx.doi.org/10.1073/pnas.0530291100

[6] WRIGHT MH, CALCAGNO AM, SALCIDO CD, CARLSON MD, AMBUDKAR SV et al. Brcal breast tumors contain distinct CD44+/CD24- and CD133+ cells with cancer stem cell characteristics. Breast Cancer Res 2008; 10: R10. http://dx.doi. org/10.1186/bcr1855

[7] MA S, CHAN KW, HU L, LEE TK, WO JY et al. Identification and characterization of tumorigenic liver cancer stem/progenitor cells. Gastroenterology 2007; 132: 2542-2556. http://dx.doi.org/10.1053/i.gastro.2007.04.025

[8] YIN S, LI J, HU C, CHEN X, YAO M et al. CD133 positive hepatocellular carcinoma cells possess high capacity for tumorigenicity. Int J Cancer 2007; 120: 1444-1450. http://dx.doi. org/10.1002/ijc. 22476

[9] MA S, CHAN KW, LEE TK, TANG KH, WO JY et al. Aldehyde dehydrogenase discriminates the CD133 liver cancer stem cell populations. Mol Cancer Res 2008; 6: 1146-1153. http://dx.doi.org/10.1158/1541-7786.MCR-08-0035

[10] RICCI-VITIANI L, LOMBARDI DG, PILOZZI E, BIFFONI $\mathrm{M}$, TODARO $\mathrm{M}$ et al. Identification and expansion of human colon-cancer-initiating cells. Nature 2007; 445: 111-115. http://dx.doi.org/10.1038/nature05384

[11] DALERBA P, DYLLA SJ, PARK IK, LIU R, WANG X et al. Phenotypic characterization of human colorectal cancer stem cells. Proc Natl Acad Sci U S A 2007; 104: 10158-10163. http://dx.doi.org/10.1073/pnas.0703478104

[12] O'BRIEN CA, POLLETT A, GALLINGER S, DICK JE. A human colon cancer cell capable of initiating tumor growth in immunodeficient mice. Nature 2007; 445: 106-110. http:// dx.doi.org/10.1038/nature05372 
[13] ERAMO A, LOTTI F, SETTE G, PILOZZI E, BIFFONI M et al. Identification and expansion of the tumorigenic lung cancer stem cell population. Cell Death Differ 2008; 15: 504-514. http://dx.doi.org/10.1038/sj.cdd.4402283

[14] KIM CF, JACKSON EL, WOOLFENDEN AE, LAWRENCE S, BABAR I et al. Identification of bronchioalveolar stem cells in normal lung and lung cancer. Cell 2005; 121: 823-835. http://dx.doi.org/10.1016/j.cell.2005.03.032

[15] LI C, HEIDT DG, DALERBA P, BURANT CF, ZHANG L et al. Identification of pancreatic cancer stem cells. Cancer Res 2007; 67: 1030-1037. http://dx.doi.org/10.1158/0008-5472. CAN-06-2030

[16] RASHEED Z, WANG Q, MATSUI W. Isolation of stem cells from human pancreatic cancer xenografts. J Vis Exp 2010. http://dx.doi.org/10.3791/2169

[17] HUFF CA, MATSUI W.MULTIPLE MYELOMA CANCER STEM CELLS. J Clin Oncol 2008; 26: 2895-2900. http:// dx.doi.org/10.1200/JCO.2007.15.8428

[18] JIJ,WANGXW.Clinical implications of cancer stem cell biology in hepatocellular carcinoma. Semin Oncol 2012; 39: 461-472. http://dx.doi.org/10.1053/j.seminoncol.2012.05.011

[19] SZILVASSY S, HUMPHRIES R, LANSDORP P, EAVES AEAVES C. Quantitative assay for totipotent reconstituting hematopoietic stem cells by a competitive repopulation strategy. Proceedings of the National Academy of Sciences of the United States of America 1990; 87: 8736-8740. http://dx.doi. org/10.1073/pnas.87.22.8736

[20] GRAHAM SM. Primitive, quiescent, Philadelphia-positive stem cells from patients with chronic myeloid leukemia are insensitive to STI571 in vitro. Blood 2002; 99.

[21] XU X, LIU RF, ZHANG X, HUANG LY, CHEN F et al. DLK1 as a potential target against cancer stem/progenitor cells of hepatocellular carcinoma. Mol Cancer Ther 2012; 11: 629-638. http://dx.doi.org/10.1158/1535-7163.MCT-110531

[22] YAMASHITA T, JI J, BUDHU A, FORGUES M, YANG W et al. EpCAM-positive hepatocellular carcinoma cells are tumor-initiating cells with stem/progenitor cell features. Gastroenterology 2009; 136: 1012-1024. http://dx.doi. org/10.1053/j.gastro.2008.12.004

[23] LEE TK, CASTILHO A, CHEUNG VC, TANG KH, MA S et al. CD24(+) liver tumor-initiating cells drive self-renewal and tumor initiation through STAT3-mediated NANOG regulation. Cell Stem Cell 2011; 9: 50-63. http://dx.doi. org/10.1016/j.stem.2011.06.005

[24] SUKOWATI CH, ANFUSO B, TORRE G, FRANCALANCI P, CROCE LS et al. The Expression of CD90/Thy-1 in Hepatocellular Carcinoma: An and Study. PLoS One 2013; 8: e76830. http://dx.doi.org/10.1371/journal.pone.0076830

[25] CHIBA T, KAMIYA A, YOKOSUKA OIWAMA A. Cancer stem cells in hepatocellular carcinoma: Recent progress and perspective. Cancer Lett 2009; 286: 145-153. http://dx.doi. org/10.1016/j.canlet.2009.04.027

[26] WARD RJDIRKS PB. Cancer stem cells: at the headwaters of tumor development. Annu Rev Pathol 2007; 2: 175-189. http://dx.doi.org/10.1146/annurev. pathol.2.010506.091847
[27] DALERBA P, CHO RWCLARKE MF. Cancer stem cells: models and concepts. Annu Rev Med 2007; 58: 267-284. http://dx.doi.org/10.1146/annurev.med.58.062105.204854

[28] AILLES LE, WEISSMAN IL. Cancer stem cells in solid tumors. Curr Opin Biotechnol 2007; 18: 460-466. http://dx.doi. org/10.1016/j.copbio.2007.10.007

[29] TONG CM, MA SGUAN XY. Biology of hepatic cancer stem cells. J Gastroenterol Hepatol 2011; 26: 1229-1237. http:// dx.doi.org/10.1111/j.1440-1746.2011.06762.x

[30] GOODELL MA, BROSE K, PARADIS G, CONNER AS, MULLIGAN RC. Isolation and functional properties of murine hematopoietic stem cells that are replicating in vivo. J Exp Med 1996; 183: 1797-1806. http://dx.doi.org/10.1084/ jem.183.4.1797

[31] CHIBA T, KITA K, ZHENG YW, YOKOSUKA O, SAISHO H et al. Side population purified from hepatocellular carcinoma cells harbors cancer stem cell-like properties. Hepatology 2006; 44: 240-251. http://dx.doi.org/10.1002/hep.21227

[32] ZHOU S, SCHUETZ JD, BUNTING KD, COLAPIETRO AM, SAMPATH J et al. The ABC transporter Bcrp1/ABCG2 is expressed in a wide variety of stem cells and is a molecular determinant of the side-population phenotype. Nat Med 2001; 7: 1028-1034. http://dx.doi.org/10.1038/nm0901-1028

[33] SHIMANO K, SATAKE M, OKAYA A, KITANAKA J, KITANAKA N et al. Hepatic oval cells have the side population phenotype defined by expression of ATP-binding cassette transporter ABCG2/BCRP1. Am J Pathol 2003; 163: 3-9. http://dx.doi.org/10.1016/S0002-9440(10)63624-3

[34] MONTANARO F, LIADAKI K, SCHIENDA J, FLINT A, GUSSONI E et al. Demystifying SP cell purification: viability, yield, and phenotype are defined by isolation parameters. Exp Cell Res 2004; 298: 144-154. http://dx.doi.org/10.1016/ j.yexcr.2004.04.010

[35] CHALLEN GA, LITTLE MH. A side order of stem cells: the SP phenotype. Stem Cells 2006; 24: 3-12. http://dx.doi. org/10.1634/stemcells.2005-0116

[36] XU Y, XIE Y, WANG X, CHEN X, LIU Q et al. Identification of cancer stem cells from hepatocellular carcinoma cell lines and their related microRNAs. Oncol Rep 2013.

[37] SLADEK NE. Human aldehyde dehydrogenases: potential pathological, pharmacological, and toxicological impact. J Biochem Mol Toxicol 2003; 17: 7-23. http://dx.doi.org/ $\underline{10.1002 / j b t .10057}$

[38] GINESTIER C, HUR MH, CHARAFE-JAUFFRET E, MONVILLE F, DUTCHER J et al. ALDH1 is a marker of normal and malignant human mammary stem cells and a predictor of poor clinical outcome. Cell Stem Cell 2007; 1: 555-567. http://dx.doi.org/10.1016/j.stem.2007.08.014

[39] YIN AH, MIRAGLIA S, ZANJANI ED, ALMEIDA-PORADA G, OGAWA $M$ et al. AC133, a novel marker for human hematopoietic stem and progenitor cells. Blood 1997; 90: 5002-5012.

[40] CORBEIL D, ROPER K, HELLWIG A, TAVIAN M, MIRAGLIA $S$ et al. The human AC133 hematopoietic stem cell antigen is also expressed in epithelial cells and targeted to plasma membrane protrusions. J Biol Chem 2000; 275 : 5512-5520. http://dx.doi.org/10.1074/jbc.275.8.5512 
[41] GROSSE-GEHLING P, FARGEAS CA, DITTFELD C, GARBE Y, ALISON MR et al. CD133 as a biomarker for putative cancer stem cells in solid tumors: limitations, problems and challenges. J Pathol 2013; 229: 355-378. http://dx.doi. org/10.1002/path.4086

[42] WANG S, XU ZY, WANG LF, SU W. CD133+ cancer stem cells in lung cancer. Front Biosci (Landmark Ed) 2013; 18: 447-453. http://dx.doi.org/10.2741/4113

[43] JANIKOVA M, SKARDA J, DZIECHCIARKOVA M, RADOVA L, CHMELOVA J et al. Identification of CD133+/ nestin + putative cancer stem cells in non-small cell lung cancer. Biomed Pap Med Fac Univ Palacky Olomouc Czech Repub 2010; 154: 321-326. http://dx.doi.org/10.5507/ bp. 2010.048

[44] CUI F, WANG J, CHEN DCHEN YJ. CD133 is a temporary marker of cancer stem cells in small cell lung cancer, but not in non-small cell lung cancer. Oncol Rep 2011; 25: 701-708.

[45] BERTOLINI G, ROZ L, PEREGO P, TORTORETO M, FONTANELLA E et al. Highly tumorigenic lung cancer CD133+ cells display stem-like features and are spared by cisplatin treatment. Proc Natl Acad Sci U S A 2009; 106: 16281-16286. http://dx.doi.org/10.1073/pnas.0905653106

[46] HILBE W, DIRNHOFER S, OBERWASSERLECHNER F, SCHMID T, GUNSILIUS E et al. CD133 positive endothelial progenitor cells contribute to the tumor vasculature in non-small cell lung cancer. J Clin Pathol 2004; 57: 965-969. http://dx.doi.org/10.1136/jcp.2004.016444

[47] CHEN S, HOU JH, FENG XY, ZHANG XS, ZHOU ZW et al. Clinicopathologic significance of putative stem cell marker, CD44 and CD133, in human gastric carcinoma. J Surg Oncol 2013; 107: 799-806. http://dx.doi.org/10.1002/jso.23337

[48] ISHIGAMI S, UENO S, ARIGAMI T, UCHIKADO Y, SETOYAMA T et al. Prognostic impact of CD133 expression in gastric carcinoma. Anticancer Res 2010; 30: 2453-2457.

[49] HORI Y. Prominin-1 (CD133) Reveals New Faces of Pancreatic Progenitor Cells and Cancer Stem Cells: Current Knowledge and Therapeutic Perspectives. Adv Exp Med Biol 2013; 777: 185-196. http://dx.doi.org/10.1007/978-1-4614$\underline{5894-412}$

[50] WANG D, ZHU H, ZHU Y, LIU Y, SHEN H et al. CD133(+)/ CD44(+)/Oct4(+)/Nestin(+) stem-like cells isolated from Panc- 1 cell line may contribute to multi-resistance and metastasis of pancreatic cancer. Acta Histochem 2013; 115: 349-356. http://dx.doi.org/10.1016/j.acthis.2012.09.007

[51] LEE HJ, YOU DD, CHOI DW, CHOI YS, KIM SJ et al. Significance of CD133 as a cancer stem cell markers focusing on the tumorigenicity of pancreatic cancer cell lines. J Korean Surg Soc 2011; 81: 263-270. http://dx.doi.org/10.4174/ jkss.2011.81.4.263

[52] CHEN KL, PAN F, JIANG H, CHEN JF, PEI L et al. Highly enriched CD133(+)CD44(+) stem-like cells with CD133(+)CD44(high) metastatic subset in HCT116 colon cancer cells. Clin Exp Metastasis 2011; 28: 751-763. http:// dx.doi.org/10.1007/s10585-011-9407-7

[53] FENG HL, LIU YQ, YANG LJ, BIAN XC, YANG ZL et al. Expression of CD133 correlates with differentiation of hu- man colon cancer cells. Cancer Biol Ther 2010; 9: 216-223. http://dx.doi.org/10.4161/cbt.9.3.10664

[54] PUGLISI MA, SGAMBATO A, SAULNIER N, RAFANELLI F, BARBA $M$ et al. Isolation and characterization of CD133+ cell population within human primary and metastatic colon cancer. Eur Rev Med Pharmacol Sci 2009; 13 Suppl 1: 55-62.

[55] HARAGUCHI N, OHKUMA M, SAKASHITA H, MATSUZAKI S, TANAKA F et al. CD133+CD44+ population efficiently enriches colon cancer initiating cells. Ann Surg Oncol 2008; 15: 2927-2933. http://dx.doi.org/10.1245/s10434008-0074-0

[56] LAN X, WU YZ, WANG Y, WU FR, ZANG CB et al. CD133 silencing inhibits stemness properties and enhances chemoradiosensitivity in CD133-positive liver cancer stem cells. Int J Mol Med 2013; 31: 315-324.

[57] PIAO LS, HUR W, KIM TK, HONG SW, KIM SW et al. CD133+ liver cancer stem cells modulate radioresistance in human hepatocellular carcinoma. Cancer Lett 2012; 315: 129-137. http://dx.doi.org/10.1016/j.canlet.2011.10.012

[58] SUETSUGU A, NAGAKI M, AOKI H, MOTOHASHI T, KUNISADA T et al. Characterization of CD133+ hepatocellular carcinoma cells as cancer stem/progenitor cells. Biochem Biophys Res Commun 2006; 351: 820-824. http://dx.doi. org/10.1016/j.bbrc.2006.10.128

[59] MA S, TANG KH, CHAN YP, LEE TK, KWAN PS et al. miR130b Promotes CD133(+) liver tumor-initiating cell growth and self-renewal via tumor protein 53 -induced nuclear protein 1. Cell Stem Cell 2010; 7: 694-707. http://dx.doi.org/10.1016/ j.stem.2010.11.010

[60] ATHANASSIADOU P, GRAPSA D, GONIDI M, ATHANASSIADOU AM, TSIPIS A et al. CD24 expression has a prognostic impact in breast carcinoma. Pathol Res Pract 2009; 205: 524-533. http://dx.doi.org/10.1016/j.prp.2009.01.008

[61] HUANG LRHSU HC. Cloning and expression of CD24 gene in human hepatocellular carcinoma: a potential early tumor marker gene correlates with p53 mutation and tumor differentiation. Cancer Res 1995; 55: 4717-4721.

[62] VAN WEERING DH, BAAS PDBOS JL. A PCR-based method for the analysis of human CD44 splice products. PCR Methods Appl 1993; 3: 100-106. http://dx.doi.org/10.1101/ gr.3.2.100

[63] HARN HJ, HO LI, YU CP, WANG MW, LEE HS et al. The variant mRNA isoform of human metastasis gene (CD44V) detected in the cell lines of human hepatocellular carcinoma. Biochem Mol Biol Int 1994; 32: 233-238.

[64] KON J, OOE H, OSHIMA H, KIKKAWA YMITAKA T. Expression of CD44 in rat hepatic progenitor cells. J Hepatol 2006; 45: 90-98. http://dx.doi.org/10.1016/j.jhep.2006.01.029

[65] COGLIATI B, ALOIA TP, BOSCH RV, ALVES VA, HERNANDEZ-BLAZQUEZ FJ et al. Identification of hepatic stem/progenitor cells in canine hepatocellular and cholangiocellular carcinoma. Vet Comp Oncol 2010; 8: 112-121. http://dx.doi.org/10.1111/j.1476-5829.2010.00210.x

[66] ZHU Z, HAO X, YAN M, YAO M, GE C et al. Cancer stem/ progenitor cells are highly enriched in CD133+CD44+ population in hepatocellular carcinoma. Int J Cancer 2010; 126: 2067-2078. 
[67] REGE TA, HAGOOD JS. Thy-1 as a regulator of cell-cell and cell-matrix interactions in axon regeneration, apoptosis, adhesion, migration, cancer, and fibrosis. FASEB J 2006; 20 : 1045-1054. http://dx.doi.org/10.1096/ff.05-5460rev

[68] YANG ZF, HO DW, NG MN, LAU CK, YU WC et al. Significance of CD90+ cancer stem cells in human liver cancer. Cancer Cell 2008; 13: 153-166. http://dx.doi.org/10.1016/ j.ccr.2008.01.013

[69] YANG ZF, NGAI P, HO DW, YU WC, NG MN et al. Identification of local and circulating cancer stem cells in human liver cancer. Hepatology 2008; 47: 919-928. http://dx.doi. org/10.1002/hep.22082

[70. HASHIDA H, TAKABAYASHI A, KANAI M, ADACHI M, KONDO $\mathrm{K}$ et al. Aminopeptidase $\mathrm{N}$ is involved in cell motility and angiogenesis: its clinical significance in human colon cancer. Gastroenterology 2002; 122: 376-386. http://dx.doi. org/10.1053/gast.2002.31095

[71] LIU LL, FU D, MA YSHEN XZ. The power and the promise of liver cancer stem cell markers. Stem Cells Dev 2011; 20: 2023-2030. http://dx.doi.org/10.1089/scd.2011.0012

[72] PETROVIC N, SCHACKE W, GAHAGAN JR, O'CONOR CA, WINNICKA B et al. CD13/APN regulates endothelial invasion and filopodia formation. Blood 2007; 110: 142-150. http://dx.doi.org/10.1182/blood-2006-02-002931

[73] CHRIST B, STOCK PDOLLINGER MM. CD13: Waving the flag for a novel cancer stem cell target. Hepatology 2011; 53: 1388-1390. http://dx.doi.org/10.1002/hep.24222

[74] NAGANO H, ISHII H, MARUBASHI S, HARAGUCHI N, EGUCHI H et al. Novel therapeutic target for cancer stem cells in hepatocellular carcinoma. J Hepatobiliary Pancreat Sci 2012; 19: 600-605. http://dx.doi.org/10.1007/s00534-012-0543-5

[75] DE BOER CJ, VAN KRIEKEN JH, JANSSEN-VAN RHIJN CMLITVINOV SV. Expression of Ep-CAM in normal, regenerating, metaplastic, and neoplastic liver. J Pathol 1999; 188: 201-206. http://dx.doi.org/10.1002/(SICI)10969896(199906)188:2<201::AID-PATH339>3.0.CO;2-8

[76] CHOO AB, TAN HL, ANG SN, FONG WJ, CHIN A et al. Selection against undifferentiated human embryonic stem cells by a cytotoxic antibody recognizing podocalyxin-like protein-1. Stem Cells 2008; 26: 1454-1463. http://dx.doi. org/10.1634/stemcells.2007-0576

[77] CHEN Y, YU D, ZHANG H, HE H, ZHANG C et al. CD133(+)EpCAM(+) phenotype possesses more character- istics of tumor initiating cells in hepatocellular carcinoma Huh7 cells. Int J Biol Sci 2012; 8: 992-1004. http://dx.doi. org/10.7150/ijbs.4454

[78] YAMASHITA T, HONDA M, NAKAMOTO Y, BABA M, NIO $\mathrm{K}$ et al. Discrete nature of EpCAM+ and CD90+ cancer stem cells in human hepatocellular carcinoma. Hepatology 2013; 57: 1484-1497. http://dx.doi.org/10.1002/hep.26168

[79] LEE TK, CHEUNG VCNG IO. Liver tumor-initiating cells as a therapeutic target for hepatocellular carcinoma. Cancer Lett 2012.

[80] ROSKAMS T, DE VOS R, VAN EYKEN P, MYAZAKI H, VAN DAMME B et al. Hepatic OV-6 expression in human liver disease and rat experiments: evidence for hepatic progenitor cells in man. J Hepatol 1998; 29: 455-463. http://dx.doi. org/10.1016/S0168-8278(98)80065-2

[81] YANG W, YAN HX, CHEN L, LIU Q, HE YQ et al. Wnt/ beta-catenin signaling contributes to activation of normal and tumorigenic liver progenitor cells. Cancer Res 2008; 68: 4287-4295. http://dx.doi.org/10.1158/0008-5472.CAN-07$\underline{6691}$

[82] YANG W, WANG C, LIN Y, LIU Q, YU LX et al. OV6(+) tumor-initiating cells contribute to tumor progression and invasion in human hepatocellular carcinoma. J Hepatol 2012; 57: 613-620. http://dx.doi.org/10.1016/j.jhep.2012.04.024

[83] TANIMIZU N, NISHIKAWA M, SAITO H, TSUJIMURA TMIYAJIMA A. Isolation of hepatoblasts based on the expression of Dlk/Pref-1. J Cell Sci 2003; 116: 1775-1786. http://dx.doi.org/10.1242/jcs.00388

[84] HUANG J, ZHANG X, ZHANG M, ZHU JD, ZHANG YL et al. Up-regulation of DLK1 as an imprinted gene could contribute to human hepatocellular carcinoma. Carcinogenesis 2007; 28: 1094-1103. http://dx.doi.org/ 10.1093/carcin/bgl215

[85] YAMASHITA T, FORGUES M, WANG W, KIM JW, YE Q et al. EpCAM and alpha-fetoprotein expression defines novel prognostic subtypes of hepatocellular carcinoma. Cancer Res 2008; 68: 1451-1461. http://dx.doi.org/10.1158/0008-5472. CAN-07-6013

[86] BENTIVEGNA A, CONCONI D, PANZERI E, SALA E, BOVO G et al. Biological heterogeneity of putative bladder cancer stem-like cell populations from human bladder transitional cell carcinoma samples. Cancer Sci 2010; 101: 416-424. http://dx.doi.org/10.1111/j.1349-7006.2009.01414.x 